\title{
Charles Cros'un Mémento ve Behçet Necatigil'in Sevgilerde Şiirlerinde Anakronizm
}

Yavuz KIZILÇİM

\begin{abstract}
$\ddot{\mathbf{O} z}$
Bu çalışmada Charles Cros'un Mémento/ Not alın ve Behçet Necatigil'in Sevgilerde şiirleri anakronizm açısından ele alınarak, bu şiirlerin ayırt edici özellikleri zamansal yapıda gözlemlenen değişikliklere göre irdelenecektir. Cros ve Necatigil insanların küçük hesaplarını, gündelik telaşlarını alaya alan şiirler yazmışlardır. Bu şiirlerde bir tür zaman bozumculuk ilkesiyle geçmiş ve gelecek aynı potada eritilerek, dünle bugün birbirine yakınlaştırılarak zamanın süreklilik ilkesi bilerek yok sayılmıştır. Zamansız bir geçmiş bütününde kronolojik bir zaman çizgisi ya da içeriği değil, belirli bir sürede yaşanan olayların birbiri içine girdiği durağan bir zaman görünümü söz konusudur. Her iki şiirde de, imgelerin, çağrışım nesnelerinin, insanların ve olayların gösterimi bozulan zaman düzeninde ön plana çıkarılır. Cros ve Necatigil arasındaki en açlk benzerlik gündelik yaşamı sorgulamalarıdır; her iki şairde de, bu sorgulayıcı taraf şiirdeki bağlamsal ipuçlarında değerlendirilecektir. Her ikisi de konularını gerçekle bağlarını sürdüren canlı bir kaynaktan; yani, gündelik yaşamdan almaktadır. Bu bağlamda anakronizmin Cros ve Necatigil şiirindeki etkisi seçili örnekler üzerinden değerlendirilecek ve şiirin art zamanlamalı söylemi karşlaştırma yoluyla irdelenecektir.
\end{abstract}

Anahtar kelimeler: Söylem çözümlemesi, art zamanlama, benzerlikler, sorgulama, şiir anlayışları, duyarsızlık, metalaşma.

\section{Anachronism in Poetry of Charles Cros Mémento and for The Affections Sevgilerde (In Love) of Behçet Necatigil}

\begin{abstract}
In this article, the author proposes to analyze anachronism in poetry of Charles Cros Mémento and Sevgilerde (In Love) of Behçet Necatigil according to the distinctive features seen in the structure temporal. It is employed, in particular, in order to attract the attention of the readers by an appropriate employment of times. It is considered an unintentional error that it is not quite in realtime, and it is not quite out of the real-time. When we look at the poems of Cros and Necatigil, these two poets, they laugh at the passions and small interest daily of the people. The principle of continuity in the time ignores consciously so, the past and the present mingling in the same pot in the present time. The notion of chronological time exposes in a very different way. Both have the same choking sensation and the same feeling of isolation in front of an atrocious reality that is only the visible form of a universe a materialistic. Analogy the more clear between Cros and Necatigil is to query the life of all the world. We will examine this part questioning in the contextual evidence of two poets. It is not a content poetic linear and chronological, but a process in which events intertwine. Their poetic production should be inspired by the everyday realties, or to comment its source in a world drawn from real life. In this context, the efficiency of anachronism in the structure of Cros's and Necatigil's poems is going to be evaluated via examples.
\end{abstract}

Prof. Dr., Atatürk Üniversitesi, Eğitim Fakültesi, Yabancı Diller Eğitimi Bölümü, Fransız Dili Eğitimi, ykzlcim@yahoo.fr [Makale kayıt tarihi: 7.3.2018-kabul tarihi: 14.4.2018] 
Key words: Discourse analysis, anachronism, analogy, query, design of poetry, senseless, reification.

\section{O. Giriş}

Charles Cros ülkemizde az bilinen bir şairdir. Ömrünü Paris kafelerinde tekerlemeler söyleyerek türlü işler peşinde serseriliklerle geçiren şairin değeri kendi ülkesinde bile, ölümünden yüzyll sonra anlaşılmış, eserleri yeniden basılmıştır. Olayları ve insanları alaya alan şiirler yazmıştır. Şiirini oluşturan öğelere bakıldığında, Cros'un yansıma bildiren çok katmanlı anlam ilişkilerinde kimi nitelemelerle sağladığı yinelemeli seslileri sık kullandığını gözlemliyoruz (Orhan Veli, 1963:50).

Bizim bu çalışmada aralarında özellikle zamanın kullanımı yönünden çeşitli benzerlikler bulduğumuz Cros'un Mémento/ Not alın ve Behçet Necatigil'in Sevgilerde şiirlerini tartışmaya açmak istiyoruz. Bizim örneklem olarak bu iki şiiri seçme nedenimiz şiirlerdeki zaman kullanımının anakronizm kavramının çözümüne olanak tanıyacak ölçütlere uygunluğudur. Burada, her iki şairin de kendine özgü bir söylemle kurdukları şiirlerini zaman konusunu öne çıkararak yazma yoluna gittiklerini gözlemliyoruz. Her ikisi de akışını durduramadıkları zamanın gidişatını bozarak, onunla oynayarak şiirlerini bu zamansal kopma üzerine bina etmekte, her iki şair de duygu ve düşüncelerini yalın ve etkili bir dille aktarmaktadır. Bu şiirlerin söylemi, şiirin imlediği yazınsal bağlamı, içinde "oluş"tuğu, yaşandığı zamanı an"ı"lar yığını içeriğinde özetliyor. Cros, genelde insanı, insanın küçük hesaplarını, gündelik telaşlarını alaya alan dramatik ve trajik şiirler yazarak, bunların faydalı/ faydasız "oluş"una değinide bulunmaktadır; bir nesne neye/ kime göre faydalı veya faydasızdır, diye sorguladığını görürüz. Bu açıdan bakıldığında, bütün toplumsal değerlere; özellikle, maddi değerlere çattığını ve buna bağlı olarak insanların doğru olarak benimsediği yanlış değerlere inanmadığına tanık oluruz. Onu beğenmeyen, varlığını ezen, kişiliğini yerle bir eden toplumu o, zaten hiç beğenmez ve sizin inandıklarınız benim gözümde bir hiç"tir, diyecek kadar ileri gider ve eğer deyim yerindeyse, insanların aklıyla alay ederek eleştiri oklarını toplumun en geniş alanlarına atar. Kendisine karşı yapılan haksızlıkları, onu ezen ve cezalandıran toplumu ve onun kurumlarını katı eleştirinin süzgecinden geçiren şiir bu şaşırtıcı söylemiyle, Cros şiirinin başlığında belirtildiği gibi, şiire not düşme hedefine dönük olarak yazılmış izlenimi uyandırmaktadır.

Her iki şairin de sorun olarak şiirlerine aldıkları konu büyük benzerlikler göstermekte ve söylemleri büyük oranda örtüşmektedir. İkisi de elden kaçırdıklarının peşindeler ve geçmişten şimdiki ana süregelen boşluğu doldurmanın, geçmişi onarmanın olanaksızlı̆̆ının altını çizerler. Mekân ile zaman arasında çeşitli ilişkiler mevcuttur: Bunlar yalnızca çeşitliliğin verildiği düşüncenin ve sözün ifadesi olmakla kalmazlar; bize bir de tam anlamıyla mekânsal ve zamansal bir çeşitlilik de sunarlar burada'ların çeşitliliğiiyle, şimdi'lerin çeşitliliği iç içe girer. Zamanın her an'ı mümkün bir şimdidir, mekânın her noktası mümkün bir burasıdır. Demek ki, yalnızca mekânda ve zamanda belirlenmemiş bir çeşitlilik yoktur, bizzat mekân ile zamanın tanımlanmamış bir çeşitlilikleri de vardır. Demek ki, algının olması için bir çeşitliliğin mutlaka bana verilmiş olması lazım -ama yalnız bu çeşitlilik verisi, çeşitliliğin bu alıcılı̆̆ı olsaydı hiçbir şekilde kendi başına bir algı oluşturmazdı (Deleuze, 2000:81-85).

Ele aldığımız her iki şiirde de, birbirine sarmalanmış, birbirini zamansal olarak içeren biçim ve içerik özellikleri bir ana yapıya eklemlenmiştir. Şiirsel söylemin şu an yaşanan zaman dilimi ve geçmiş arasında gidiş gelişini izlemektense onu belli bir zaman aralı̆̆ında durdurmanın peşindedirler. Şiirde verilen her ayrıntının bir bütün olarak söyleme yeni bir boyut kazandırdığını gözlemleriz; şair, iz bırakan anıları üst üste koyarak an'ların iç içe girmişliğini göstermektedir. Zamansal görünüm olarak, şiirin 
söylemi sadece yitirilmiş bir geçmişe ait değil, sürmekte olan şimdi'nin, an'ın söylemidir: bilindiği gibi zamandaki küçük, büyük değişiklikler, uzamı değiştirir. Hem Cros hem de Necatigil'de yaşanan şu an aynı zamanda bir geçmiş ve geleceği de içinde barındırır; bunlar, akan güncel zamanın bağdaşık birimleridir ve şiirde şu an sözcelenen "siz, başka türlü düşünmüştünüz hayatı" yinelemesinde açı̆̆a çıkan bir süreklilik duygusunu imlerler. Yani bir yandan günceli anlık eylemlerimizi aktaran bir ben "siz küçücük menfaatleri için çırpınan şamatacı canlılar", diğer yandan bilişsel düzeyde biz farkında olmadan geçmiş yaşantılarımızı bellekte biriktiren yani, bizim kişiliğimizi oluşturan bir ben bulunur. Geçmiş, şu an, gelecek hepsi bir unutkanlıkta, birbirine karışır, iç içe geçer ve zaman-uzam bağıntısını bir kez daha imler: "Hamiline çekler, kanallar, evler, bunlar sizin yatırım saydıklarınız" dizesinde özne doğrudan okura, siz diye seslenirken bu siz, özünde bizi de kapsar. İşte zamanda bozumculuk da buradan, bu zaman-uzam birlikteliğinden kaynaklanır; her iki şiirde güncelle, geçmişi aynı planda bir araya getiren şiir dilinin gerekçesinin bu kipsel bağdaşıklığa koşut olarak geliştiğini anlarız. Buna karar veren bilişselliğimiz; yani, boylu boyunca yaşamımızı dolduran ve onu an'lık bir zaman diliminde donduran zaman bilgimizdir. Zamanın sürgit düzeni bozulduysa bunun gerçek nedeni toplumsal üretim-tüketim ilişkileri içinde görülen ağır biçimsel bozulmadır. Şairin, şimdiyi şiirine taşımasına olanak sağlayan geçiş aracının bu yakın/uzak geçmişe ait izler olduğunu haber verir. Ahmet Oktay'ın belirttiği gibi: Şimdiki zaman, yaşayan insanın yaşamını ürettiği zamandır. Dolayısıyla çalışmadır, yoksulluk ve yoksunluktur. Dahası, hem yasal hem törel düzeyde baskı ve kısıtlamadır (Oktay, 1995:28). Şair kimliğini oluşturan geçmiş onun şu an aktardığı söylemlere ışık tutar ve onun şimdi'si bu geçmişin eskileriyle güncelleştirilir. Çözümlemede bir bütün olarak zaman konusunun ağır bastığı şiirlerin seçilmesi bir zorunluluk olarak görünmektedir; öncelikle, Charles Cros'un, Mémento/ Not aln şiirini okuyalım:

\section{Zaman Kavramı ve Anakronizm İlişkisi}

\section{Charles Cros, Mémento/ Not aln}

Michel Eudes'e

1 Les êtres trépignants, amoureux de l'utile, (Siz menfaat için çırpınan şamatacı canlılar,)

2 Passent le temps fuyard à des combinaisons (Zaten yerinde durmayan zamanı, küçük hesaplar uğruna harcayanlar)

3 D'actions au porteur, de canaux, de maisons (Hamiline çekler, kanallar, evler, bunlar sizin yatırım saydıklarınız,)

4 De commerce, où leur sens s'éteint ou se mutile. (Bir süre sonra önemi kalmayacak ya da omurgasını yitirecek anlamlar,)

5 D'autres ont ici-bas un but aussi utile, (Biraz faydalı iş yapanlar da yok değil, şu ölümlü dünyada)

6 Fabriquant des tableaux, des vers, des oraisons, (Eserleri arasında vardır tablolar, dizeler, yakarışlar,)

7 Cela, pour que leur nom, durant quelques saisons, (Görünsün diye adları çim pistlerde kazanan at isimlerinin yanında)

8 Près des noms des chevaux vainqueurs au turf, rutile. (Belki birkaç mevsim sürer tüm bu çabalar)

9 Vous avez pris la vie autrement. Vous pensez (Siz, başka türlü düşünmüştünüz hayatı,)

10 Que l'agitation incessante, illusoire, (Düşünün bir küçük akla biçilmiş roldür)

11 N'est pas œuvre de Dieu, mais rôle d'infusoire. (Tanrı'nın işi değil, bu biteviye ajitasyon ve kuruntular.)

12 A rire en plein soleil croyez bien dépensés (Lay, lay, lom ile geçeceğine nasıl da inanırsınız,)

13 Les lugubres instants d'un monde provisoire, (Geçici dünyanın kasvetli anlarını)

14 Et n'enlaidissez pas comme les gens sensés. (Ve akıllı insanlar olarak çirkinleştirmezsiniz onları) (https://www.poemhunter.com/poem/mémento-7, Türkçesi makalenin yazarına aittir). 
Bu söylemlerde anlam alanı kapalıdır, şair gerçekte kime seslenmektedir? Bilindiği gibi, Cros'un şiirini adadığı Michel Eudes ressam ve denizcidir. Şiirin öznesi kendini soyutladı ̆̆ı, diğer insanlardan (êtres trépignants) istekleri karşılanmayınca yaygara koparan, çocuk davranışında gözlemlediği gibi tepinen canlılar diye söz eder; yani, insanlarla dalga geçerek aklınızı kullanmadan hareket ediyorsunuz, aklı olanlar menfaatin değil, insanlığın peşine düşerler, der. Tepkisiz, bir nesnel anlatı altında gizlenerek, ben'den biz'e doğru ilerler, korkak ve edilgen tepkiler vererek küçük hesapların peşinde gidiyorlar, derken bu sözü sanki onları dışarıdan, bir camekanın ardından seyrediyormuş, kafesteki hayvanlara bakıyormuş gibi söyler. İşkencecisine hayran, celladına aşı kurbanlar kimliğinde konuşan özne (amoureux de l'utile/ menfaat sevdalısı) sevdalı sözünü kullanarak aşık olan insanların akıllarını kullanmadan gözü kapalı sevdalarının peşinden gitmelerine gönderme yaparak faydanın neye faydalı olduğunu sorgulamadan faydalı olduklarına inananları daha çok maddi doyumsuzluk açısından eleştirir.

Cros şiirinin dokuzuncu ve onuncu dizelerinden; vous avez pris la vie autrement. vous pensez (siz, başka türlü düşünmüştünüz hayatı,/ bu biteviye ajitasyon ve kuruntuları) ve benzer şekilde, Necatigil şiirinin onuncu dizesinden anlaşllacağı gibi: Siz geniş zamanlar umuyordunuz ve parantez içinde yazılan (siz böyle olsun istemezdiniz) dizelerinde sezdirilen anlamlarıyla, her ikisinin de, mevcut zaman dilimindeki mutsuzluklarını gidererek bir başka zaman planı kurmak istedikleri açıktır. Bu tür zaman bozumculuk (anakronizm, art zamanlama), (Karataş, 2001:30-31) ilkesiyle, geçmişle gelecek tüm zaman dilimlerinde aynı potada eritilerek, dünle bugün birbirine yakınlaştırılarak zamanda sürerlilik ilkesi bile isteye yok sayılmaktadır. Zamansız bir geçmiş bütününde zaman kavramının kendisi yok edilerek, okura değişik bir biçimde sunulur: buna bağlı olarak, kronolojik bir zaman çizgisi ya da içeriği değil, belirli sürede yaşanan bütün olayların birbiri içine girdiği durağan bir görünüm söz konusu edilmektedir. Anakronizm ait olmadığı bir zamana yerleştirilen kişi veya olayları belirlemek için kullanılan bir söz sanatıdır: olayları birbirinden ayırmak veya evrensel bir benzerlik ve zamansızlığın altını çizmek için bilerek de kullanılabilir; sanat kaygısıyla, bir olayın kesin tarihinin belli olmasını engellemek için yapılır. Bu da söylem kipinin şimdiki/geniş zaman olmasını ön koşul olarak gerektirir; ayrıca, geniş zaman sözünden anlaşılması beklenen insanların zamanının bol olduğu, işin maddi boyutunu bu kadar yoğun yaşamadıkları zamanlara yapılan bir göndermedir. Geçmişten geleceğe bir sürerlilik ilkesiyle, kendine dışarıdan bakarak aynı zamanda hem içeride, hem dışarıda bulunarak; eğer deyim yerindeyse, genellemeye giderek, bütün bir ömrü şu an yaşanan zaman diliminin içine sığdırarak, zamanın hem içinde, hem de ötesinde bir yerde bulunduğunu haber verir.

Her iki ozanın da şiirlerine sinen bu sıcaklık içten içe duyulur; bunun nedeni, şairlerin özel yaşamlarını daha çok yansıtmalarıdır. Böylece, öznenin yaşadığına kanıt oluşturacak duygularının şiirin başat unsurlarını oluşturması bu yansıtmanın bütünüyle kişisel bir belirtisi olarak görülebilir: Bunun için hep yok, çünkü hep "var olana" karşıt. Karşıtları her zaman olmayan nesnelerin ise olması da olanaklı, olmaması da, onlar için oluş ve yok oluş söz konusu. Nasıl çember kendi içinde içbükey ve dışbükeyse aynı şekilde zaman da hep başta ve sonda; bu yüzden de hep değişik görünüyor, çünkü "an" aynı şeyin başlangıcı ve sonu değil, yoksa aynı nesnede karşıt şeyler zamandaş olarak bulunurdu. Demek ki zaman bitmeyecektir, çünkü hep başlangıç içindedir (Aristoteles/ Augustinus/ Heidegger, 1996:15-16).

Şiirde ölçü kullanmamasına karşın bölüm sonlarında yinelenen illusoire (aldatıcı)-infusoire (haşlak)provisoire (geçici) gibi seslilerle de örtük bir zamansal uyum sağlanmış olur. Aynı şekilde, Necatigil de, Cros'unkine benzer bir söz varlığıyla elden kaçırdıklarını, sevgisiz insan ilişkilerini (çirkindi dar vakitlerde bir sevgiyi söylemek) sözleriyle sen-ben ilişkisi bağlamında aktarmaktadır. Özellikle, Cros'un şiirinde gündeme gelen piyasa ekonomisinin yol açtığı maddi sorunlar, kişiler arası rekabet ortamının 
doğurduğu olumsuzluklar karşısında bunalan çă̆ insanını resimlemektedir. Özneye, yaşadıkları bütün olumsuzluklar bir tür kişiler arası iletişim kopukluğu ve sevgisizlik nedeniyledir, diye düşündürür. Bu haliyle, her iki şairde, kent insanının bilinç düzeyini daha çok maddi doyumsuzluk açısından eleştirmektedir; kısaca söylemek gerekirse, onların şiiri olaylara ve insanlara bir üstten bakışı haber verir. Yaşamının belirli bir anını ve o anda rol oynayan belirli bir özneyi şiirine konu olarak seçer.

Özne şiirin bütününde aynı yapıyı kullanarak ilki olumlu, ikincisi olumsuz iki karşıt düşünceyi aynı dizede bir araya getirerek açımlamayı ve bu yolla okuru şaşırtmayı dener. Oluş'ların içkin düzeninde faydalı (oluş), faydasız (oluş), ölümlü (oluş), algılanabilir veya algılanamaz (oluş) birlikte hareket ederler, bu birliği sağlayan farklı oluş'tur: Bu durum bizi bir başka egemenlik alanıyla, bir başka türle bağlantılı kılan bir değişime ulaştırmaktan ibarettir. Nesne+oluş süreçleri ozanın sözcülüğünü üstlendiği tüm insanlık adına yarattığı ve sürdürdüğ̈ varlıksal genişlemelerdir. Gerçekte, bu nesne+oluşların tümü birbirleriyle iletişim durumundadırlar. Dahası kurdukları iletişimin sesini yalnızca özne duyar ve duyurur. Deleuze kadın (oluş)un genel koşul, hayvan (oluş)un, oluş'un özel bir koşulu olduğunu dile getirir. Bu (oluş)ların her birinde yalnızca algılanamaz (oluş) değişiminini tamamlar veya bir ön gerçeklik anlayışı yaratır; çünkü, bir yaşam uzamı veya düşünce aralı̆̆ı bu evrensel görüntüde yeniden resmedilir: Yeniden üretilen her şey kişisel niteliklerinden arındırılmıştır: Özel bir ismin hiçbir anlamı bulunmaz, belgisiz tanımlıklar hiç de belirsiz değildirler; bir düşünce formülünde biçimlendikleri zaman bu belgisiz tanımlıklar, bir çocuğun ya da bir şiirin sözlerinde daha çok mevcut durumu nitelendiren bu ortak gücü dile getirirler. Mastar eylem, bedensizlerin Stoacı gramerinde olduğu gibi, eylemi bir zamana, bir yere ve bir özneye göre konumlandırmaktan daha çok bu eylemin oluşuyla ilgilenmenin söz konusu olduğunu vurgular. Hiçbir şey bir olaydan, yani bir oluştan daha belirleyici değildir; öyleyse, hiçbir şey daha az öznel değildir (David-Ménard, Türkçesi makalenin yazarına aittir, 2005:106).

Cros aşağıdaki dizelerde, être trépignant, (tepiniyor oluş)

être amoureux, (sevdalı oluş)

sözcelerini kullanarak, dörtlüğün bütününde bir ironi/alay söylemi kurmuştur. Yazarın sözlerine muhatap olanlar aslında tercihlerini kendi akıllarıyla yapabilecek bilinçli insanlar olmalarına karşın, oluş "être" sözünün kullanımıyla bütün yaratılmışlara gönderme yapılmış ve insanla, hem duyuları olmayan cansızlar veya bilinçten yoksun otlar ve yine akıldan yoksun hayvanlar arasında söylem düzeyinde duygu birliği sağlanmıştır. "Amoureux" nitelemesiyle tanımlanan özne, hiçbir şeyi sorgulamadan, gözü kapalı bir aşk macerası peşine düşenlere benzetilerek, insanın asıl fayda'nın nerede veya ne (oluş)ta bulunduğunun farkına varamaması eleştirilmektedir: Varolma, benim varolduğum bir varolan oluyorsa ve aynı zamanda başkası ile olmak olarak tanımlanıyorsa, benim varolmam çoğu kez ve genelde ben kendim değilimdir, başkalarıdır. Varolma şu andalıktadır; o olabildiği şey olduğu sürece hep benimkidir. Ben başkalarıyla varolurum ve başkaları da başkalarıyla (Aristoteles/ Augustinus/ Heidegger, 1996:73-77).

Yerinde durmayan zamanın avuçları arasından akıp gitmesine ek olarak birde insanın bu zamanı aslında önemi ve faydası dokunmayan eylemlere boşuna harcamış olması, boş işlerle oyalanıyor olması, onun karşısına, şairin sert eleştirisini çıkarmıştır. Şair yaşadığı çağa göre, sosyal yaşantı içerisinde kavramlaşan "porteur ve canaux" (hamiline çekler, kanallar, evler) gibi insanların yatırım nesnesi saydıkları maddi nesneler bir bakıma da materyalizmi ve anamalcılı̆̆ı veya insandan, insani değerleri ve emeğini hissettirmeden çalan sermaye düzenini eleştirmektedir. "D'actions au porteur, de canaux, de maisons, de commerce" (hamiline yazılı çekler, kanallar, evler, bunlar sizin yatırım saydıklarınız) gibi 
sözcelerin eleştiri aracı olarak kullanılması, okura üstü örtük bir biçimde, insani duyguların ve düşüncelerin de eleştirisinin yapıldığını düşündürür. Bu bağlamda, şiirine konu olarak seçtiği her şey Cros'un eleştirisinden payını alır; buna ekonomik yatırım araçlarını da dahil ederek, toplumsal yapıları eleştirel mercek altına almaktadır.

"Passent le temps fuyard à des combinaisons", (zaten yerinde durmayan zamanı, küçük hesaplar uğruna harcayanlar)/ d'autres ont ici-bas un but aussi utile, (biraz faydalı iş yapanlar da yok değil, şu ölümlü dünyada)/ Que l'agitation incessante, illusoire/ (Tanrı'nın işi değil, bu biteviye ajitasyon ve kuruntular) les lugubres instants d'un monde provisoire (geçici dünyanın kasvetli anlarını) dizeleri şiirin ana omurgasını oluşturan dizelerdir. Burada anılan bütün insanlara "les êtres trépignants, amoureux de l'utile" (sizler menfaat için çırpınan şamatacı canlılar) diye seslendikten sonra "à rire en plein soleil croyez bien dépensés" (lay, lay, lom ile geçeceğine nasıl da inanırsınız) diye sorarak anlamlı bir yaşam sürdürdüklerini ve güzel işler yaptıklarını sanarak ruhsal doyum arayan; ancak, aslında küçük menfaatleri, çıkar hesapları için çırpınan varlıkların boş, önemsiz ve anlamsız olaylara seyirci kalışları arasında lak lak ile ömür geçirmekte, boşa zaman öldürmekte sayılmalıdır.

"Ici-bas" karşıtlığı, sözlükte fanilik çağrışımı yapıyor: Dünya yaşamının geçiciliğini dini duyguların coşumuyla açıklayan bir anlamın şiirdeki karşılığıdır. Söz konusu sözcede, aynı zamanda, "le but" (amaç) sözcüğü de yer almaktadır. Şiiri sözceleyen özne "ici-bas un but aussi utile" (biraz faydalı iş yapanlar da yok değil, şu ölümlü dünyada) dizesinde ölümlü dünyada kalıcı/faydalı hedeflere yönelmek ifadesinin yanında, kalıcı ve bütün insanlığa yararlı işler yaptığını sanan ressamlar, din adamları ve hatta mühendislerin bu düşüncelerinin yapay ve bütün bunların yapılmasının arka planında bu kişilerin isimlerinin saygıyla anılması, saygınlık taşıması ve birkaç mevsim boyu kendilerinden söz edilmesi gibi kabarık egolarının bulunduğuna dikkat çekmektedir.

\section{Sevgilerde Şiirinde Zaman Tasarımı}

Şimdi Necatigil'in Sevgilerde şiirini okuyalım:

Sevgilerde

1 Sevgileri yarmlara biraktımiz

2 Çekingen, tutuk, saygilı.

3 Bütün yakılarmız

4 Sizi yanlış tanıdı.

5 Bitmeyen işler yüzünden

6 (Siz böyle olsun istemezdiniz)

7 Bir bakış bile yeterken anlatmaya her şeyi

8 Kalbinizi dolduran duygular

9 Kalbinizde kaldı.

10 Siz geniş zamanlar umuyordunuz

11 Çirkindi dar vakitlerde bir sevgiyi söylemek.

12 Yıllarm telâşlarda bu kadar çabuk

13 Geçeceği aklınıza gelmezdi.

14 Gizli bahçenizde

15 Açan çiçekler vardr,

16 Gecelerde ve yalnzz.

17 Vermeye az buldunuz

18 Yahut vaktiniz olmadr (Necatigil, 2012:131). 
İçtenlik ve sevgi bağlamında bir araya getirilen iki değişik davranış biçimi, şiirde açıkça belirtilen gizli duyguların ortaya çıarılmasına yarıyor ve kötücül duyguların eşliğinde devinimsizlik, edilgenlik, zamana ve uzama hakim olamama duygularında bir araya getirilmektedir. Şairlerinden ötürü bir erkeğe ait olduğunu düşündüğümüz bu yaşam biçimi sözü edilen erkeklerin yalnız kalışlarını, dar tıkış yerlerde geçen ve dış dünyayı yalnızca seyreden bakışlarını resimler. Şiirde "siz" diye seslenilen şiirin öznesi doğal ortamında gözlemlenmekte ve okura onun hakkında bilgiler verilmektedir. Bu edilgen yaşam biçimi çekingen, tutuk bir kişiliğin göstergesi olarak sunulur ve geleceğe dönük iyicil tasarımları vaktinden evvel boşa çıkarılır. Şiirin öznesi kendini öteki düşük ücretle çalışanlarla eşitleyerek kendinin de onlar gibi, en az onlar kadar küçük, işe yaramaz, tekdüze bir varlık olarak duyurmaktadır: Bir türlü "bitmeyen işler yüzünden". Her iki şiir de insan davranışı üzerine çeşitli saptama ve yargllamalardan oluşmaktadır: özne giderek metalaşan toplumsal yaşamı değişik nesnelerle belirlemeyi sürdürür ve paranın büyüsüne kapılan insanların çıkmazlarını ve açmazlarını sorgular. Şair dokunaklı duyarlığını "siz geniş zamanlar umuyordunuz" dizesiyle anlatmaktadır: daha yaşayacak çok zamanım var, diye düşünüyordunuz; on ikinci ve on üçüncü dizelerde belirtilen "yılların telâşlarda bu kadar çabuk/ geçeceği aklınıza gelmezdi" bu nedenle, gönlünüzden geçenleri sürekli ertelediniz ve sevdiklerinizi ihmal ettiniz, diye karşı bir söylem geliştirir. Sevgilerde şiirinin on beşinci dizesinde dile getirilen (çirkindi dar vakitlerde bir sevgiyi söylemek) sözünden şu anlaşılır: size göre, bu kadar yoğun duyguyu bu kadar dar zamana sığdırmak sözcüğün tam anlamıyla "çirkin"dir. O halde işleri zamana yaymak, hiç sonu gelmeyecekmiş gibi sanılan geniş zamanlar ummak, yaşanan şu "an"ı erteleyerek geleceğe dair şeyler tasarlamak yanlış bir yol olarak gösterilir. Yapacak bir işiniz, söylenecek bir sözünüz ve gösterilecek bir sevginiz varsa bunu, bugünden gösterin, ilerde bunları yapacak yeteri kadar zamanı bulamayabilirsiniz. Yani, vakit daralmış ve ölüm hazırlıksız yakınlaşmıştır; bunu şiirin belirli geçmiş zamanda yazılmasından anlarız. Ölüm, acı ve yalnızlık karşısında özne güçsüzdür; ama, seçilen fiillerin geçmiş zamanda çekimlense de kullanılan zaman belirleyicileriyle geleceğe dönük bir anlam içerdiği görülmektedir: "Sevgileri yarmlara brraktınz", dizesinde bırakmak fiili gelecekteki, ileri bir tarihe ertelemek anlamındadır. Ardından, (Siz böyle olsun istemezdiniz) dizesinde yine gelecek söylemi öne çıkarılır. Şiirin onuncu dizesinde yer alan Siz geniş zamanlar umuyordunuz, ifadesi yine "ummak" fiilinin anlamıla "geniş zamanlar"ı da işin içine ekleyerek geleceğe yönelik olarak geçmişte sözcelenen zamanı bozmakta bugüne ve bir an için bile olsa geleceğe aktarmaktadır. Sevgilerde şiirinin on ikinci ve ön üçüncü dizelerinde "yıllartn telâşlarda bu kadar çabuk/geçeceği aklınıza gelmezdi" ifadelerinde "çabuk geçmek" ve "akla gelmek" fiilleri bir kez daha geleceğe gönderen anlamlar taşımaktadır. Örneklerde açıkça görüldüğü gibi, geçmişin bugüne ve geleceğe aktarılan yanları her zaman olumsuz yanlarıdır. Yaşadığı, tanığı olduğu her an, her yeni zaman dilimi özneye geleceğin olumsuzluğu konusunda bir fikir vermektedir.

Cros'la aynı sözcüğü kullanan Necatigil "çirkindi dar vakitlerde bir sevgiyi söylemek" derken, "çirkin" oluşu kullanmayı tercih ederek, Cros'la benzer "geçici bir dünyanın yaslı anlarını/ aklı başında insanlar olarak çirkinleştirmeyecektiniz" diyerek çirkinleştirme anlamını sürdürür ve korur. Geçirdiğiniz acı dolu yaşam, yüzünüze dolan kırışıklıklarla, neredeyse yüz şeklinizin değişmesine neden oldu, diyerek zamanın bir yandan da insanları çirkinleştirdiğini haber vermektedir. Burada, geçmişin günümüze kadar ulaşan parçaları bilinçaltında saklanmakta ve sezdirim yoluyla dar zamanlarda veya yaslı anların şiirsel zamanı içinde sözcelenmektedir. Yaşanan şimdi öylesine geçiştirilen bir zaman dilimi, özlemle gelmesi beklenen gelecek ise yarınlara bırakılan mutlulukların habercisidir: Demek ki, zaman zaten şimdiki zaman olarak açıklanmış oluyor. Geçmiş zaman artık-olmayan-şimdiki zaman olarak, gelecek zaman belirsiz henüz-olmayan-şimdiki zaman olarak yorumlanmış oluyor (Aristoteles/ Augustinus/ Heidegger, 1996:91). 
Mutluluk insanlar arası ilişkileri güzelleştiremiyorsa bile, çirkinleştir(me)mek üzerine kuruludur. Burada, bireyselliğin ve aç gözlülüğ̈̈n yoğun yaşandığı bir dünya tasarımı çizilir. İnsanlı̆̆ın iyice örselendiği bir dünya söz konusu edilir. Özneyle sevilen kadın arasında engel gibi duran büyük kentin keşmekeşinde özneyi bunaltan iş ile ev arasında geçen dar zamanlardır. İnsanlar günlük yaşamın telaşı içinde, ellerinden bir şeyi kaçırma, yetişememe duyguları arasında bunalarak aşka da zaman ayıramazlar.

"Sevgileri yarmlara buraktını" Sevgilerde başlıklı şiirin bu ilk dizesinden anlaşılan mevcut zamandan bir kopuş bağlamında, geçmişte bıraktınız, şimdi bırakıyorsunuz, gelecekte de (yarınlara) bırakacaksınız anlamıdır: Bu dize bize, öznenin gerçek yaşamında çevresinden yeterince sevgi görmediği için sevgileri yarınlara bırakmış olabileceğini de düşündürür. Bu sevgisizliğe ek olarak, dördüncü dizedeki (bütün yakınlarınız sizi yanlış tanıdı) söylemi, yanlış tanıdı ve tanımaya da devam ediyordur; çünkü, bitmeyen işler yüzünden, siz hep ikinci dizedeki (çekingen, tutuk, saygılı) nitelemeleri de sanki zamanda süreklilik bildirir gibi, her zaman sahibi olduğunuz, yinelediğiniz davranışlarınız yakınlarınızın siz yanlış tanımalarının asıl gerekçesini oluşturmuş̧tur:

-çekingen oluş

-tutuk oluş

-saygilı oluş

Bunlar zamanla sizin kişiliğinizi/varlık sebebinizi oluşturan olumsuz nitelemelere dönüştü ve sizin için yaşam içinden çıkılmaz bir hal aldı. Necatigil'in bakışıyla, kendimizi onun yerine koyarak niyetini okuduğumuzda, şöyle dediğini duyarız: aslında çok bir şey yapmamıza gerek yok, içten bir bakış bile çok şeyi anla(t)maya yeterlidir. Ama biz bunu yapmadık, yakınlarımızdan bunu esirgedik ve sonuçta kalbimizi dolduran bütün iyicil duygular, kalbimizin bir köşesinde saklı kaldı.

Şiirin alt katmanında sezdirildiği gibi, sevgiliyle ilişki kurma biçimi hem sevgi, hem nefret, hem de ona açıl(ma)ma şeklinde gelişmektedir. Şiirde çekingenliği yüzünden duyarlı, duygusal ve acı çeken bir özne görünümü çizilir; yani, sokaktaki adamın dar ve boğuntulu iç dünyası gözler önüne serilir.

\section{Sevgileri yarmlara biraktınz \\ Çekingen, tutuk, saygill. \\ Bütün yakmlarmız \\ Sizi yanlış tanıdr.}

Yani, okura, siz diye seslenerek, onu bir tür zamansızlık içine çekerek siz önceden de böyle çekingen, tutuk ve gereksiz bir biçimde saygılıydınız, der. Çevresinde tanığı olduğu dünyayı o dünyaya ait (küçük hesaplar peşinde)/ (hamiline yazılı hisse senetleri, kanallar) gibi nesnelerle tanımlamayı sürdürür. Bunun gerçek nedeni, insanların yaşadıkları zaman diliminde (u)mutsuz olmalarıdır. İçsel (u)mutsuzluk belirli bir an içinde sabitlendiğinden durdurulmuş ve dondurulmuş bir tek zaman dilimi içinde algılanmaktadır. Mali ya da parasal ilişkiler insanın önünü kesen engeller olarak esenliksiz duygu değerlerini imler ve doyumsuzluğunu çoğaltır. Şiirin öznesi "siz böyle olsun istemezdiniz" dizesindeki anlamda (mümkün olsa) bu kötücül duygulardan, olumsuz uzamdan ve zamandan şiir yoluyla da olsa kaçıp kurtulmak niyetindedir; yani, zamanın hızlı akışı bu ayarı bozulmuş zaman diliminde bir tür "bitmeyen işler yüzünden" eksiğini tamamlamaya koşan ama yetişemeyen bir özne üzerinden duyurulmuştur.

Oysa, yıllar telâş içinde, günlük yaşamın karmaşası içinde çok çabuk geçti; siz bitmeyen işleriniz yüzünden bu kadar hızlı geçtiğinin farkına bile varmadınız. Hızlı geçeceği aklınıza gelmezdi; çünkü, gizli 
bir bahçeniz vardı ve bu size özel bahçeye kimseyi, en yakınlarınızı bile yaklaştırmıyordunuz; orada, herkesten saklı tuttuğunuz çiçekleriniz vardı. Siz gecelerde yalnız kaldınız, yalnız kalmayı bilinçli olarak seçtiniz. Sevgilerinizi bu haliyle başkalarına vermeye az buldunuz veya az bulmadınız da verecek zamanınız olmadı. Böylece, bütün yakınlarınızın sizi sevgisiz tanımasına yine siz neden oldunuz.

Gerek Cros'ta, gerek Necatigil'de arka planda kanallarıyla, köprüleriyle büyük şehir resmi çizilmiş ve senetlerle, faturalar bu resme iliştirilmiştir. Önceden yaşadığı olayları ve karşılaştığı insanları anımsadığında öznenin geçmişte bir şeyleri eksik bıraktığına dair izlenimi güçlenmekte ve yalnızlı̆̆ı çoğalmaktadır: Kalbinizi dolduran duygular/Kalbinizde kaldı.

Üstelik, Necatigil'in diğer şiirleriyle birlikte düşünüldüğünde şiirin öznesinin derin duygusallı̆̆ı ve heyecanlı kişiliği insan olmanın ilk koşulu olarak gösterilmektedir. Bilinç ve farkındalık ekseninde geçmişle gelecek arasında kurulan düşlerin insan davranışını sınırlandırdığını görürüz ve şiirin öznesinin bakışını karanlık geçmişe döndürerek hem aşk, hem yaşam karşısında dik duramadığını belirler.

Şiirde geçen (siz böyle olsun istemezdiniz) parantez içi cümlesi gerekli bir açılama cümlesi olarak şairin asıl niyetini açık etmesi bakımından şiirdeki yerini almış görünür. Bu nedenle, şiirin tümünde geliştirilen bilişsel unsurları etkinleştirir. Öznenin niyetini önceden belli eden yoksul yaşantısını imlemek için yazılan, kendi kişiliğini ortaya koyan dizelerdir. Yalnızca erkeklerin gözüyle algılanan derinden derine gizli bir kadının varlığı duyurulmaktadır. Ancak kadın çok yakından tanınan bir kadın değildir; belki, geçmişte bir yerlerde hayallerle gerçekler arasında unutulmuş, arzulanmış bir kadına sosyal eleştiriyle bireysel bir sorun arasında gelişen üstten bir bakış söz konusudur. Her iki şairin de, ekonomi ağırlıklı bir söylemi dile getirmelerinin rastlantısal olmadığı söylenebilir. Ekonomik açıdan yaşanan yoksunluklar her iki şairin de (u)mutsuzluğunu çoğaltır.

\section{Sonuç}

Gerek Cros'nun Memento/ Not alın ve gerek Behçet Necatigil'in Sevgilerde şiirlerinde insanlar arası ilişkileri simgeleştirmekle yetinmeyen ve insanların; özellikle, erkeklerin bireysel sorunlarına eğilen kimi yönlerin bulunduğunu belirtmeliyiz. Her iki şairde de, imgelerin, çağrışım nesnelerinin, insanların ve olayların bozulan zaman düzeninde gösterimi ön plandadır.

Cros ve Necatigil arasındaki en açık benzerlik gündelik yaşamı sorgulamalarıdır; bu sorgulayıcı tarafı her ikisinde de gözlemledik. Her iki şiir de konularını gerçekle bağlarını sürdüren canlı bir kaynaktan; yani, gündelik yaşamdan alırlar. Her ikisi de yaşanan şu an'ın, aynı zamanda, bir geçmiş ve geleceği de içerdiğini, bunların akan güncel zamanın bağdaşık birimleri olduğunu ve Sevgilerde şu an sözcelenen (çekingen, tutuk, saygılı) yinelemesinde açığa çıkan bir süreklilik duygusunu belirlediğini bulguladık. Yani bir yandan günceli anlık eylemlerimizi aktaran bir ben (siz küçücük menfaatleri için çırpınan şamatacı canlılar), diğer yandan bilişsel düzeyde biz farkında olmadan geçmiş yaşantılarımızı arşivleyen yani, bizim kişiliğimizi oluşturan bir ben bulunur. Geçmiş, şu an, gelecek hepsi bir unutkanlıkta birbirine karışır, iç içe geçer: (Hamiline çekler, kanallar, evler, bunlar sizin yatırım saydıklarınız) dizesinde doğrudan okura siz diye seslenirken bu siz, özünde bizi de kapsar. İşte zamanda bozumculuk da buradan, bu çoklu ilkeden kaynaklanır; her iki şiirde de güncelle, geçmişi aynı planda bir araya getiren şiir dilinin gerekçesinin bu kipsel bağdaşıklıktan ileri geldiğini saptadık. Buna karar veren bilişselliğimiz; yani, boylu boyunca yaşamımızı dolduran ve onu an'lık bir zaman diliminde donduran zaman bilgimizdir. İncelenen her iki şairin de, şiirlerini şimdi üzerine kurmasına olanak sağlayan bu tür 
bir zaman bozumculuktur. Onların şair kimliğini oluşturan geçmişin, şu an aktardığı söylemlere ışık tuttuğunu ve şimdi'yi bu geçmişin kendine özgü renkleriyle yeniden yapılandırdığını gördük. Son çözümlemede, şiirin bilişsel yanı gereği, her iki şairin de insanla yaşadığı özel ilişkiyi, geçmişin hesabını vererek, geçmişte yaşananları sorgulayarak yeniden kurguladıklarını gözlemledik.

\section{Kaynakça}

Aristoteles/ Augustinus/ Heidegger (1996) Zaman Kavramı, Saffet Babür çevirisi, Ankara: İmge Kitabevi Yayınları,

Cros, C. (2012). 175 poems classic poetry series/www.poemhunter.com https://www.poemhunter.com/poem/memento-7/. Le coffret Santal, Paris: Editions Ligaran.

David-Ménard, M. (2005). Deleuze et la Psychanalyse, L'altercation, Paris: PUF.

Deleuze, G. (2000). Kant Üzerine Dört Ders, Türkçesi; ulus_baker@körotonomedya, Ankara:Öteki Yayınevi.

Dupriez, B. (1984). Les Procédés littéraires, Paris: Union générale d'Editions.

Gencan T. N, Ediskun H, Dürder B, Gökşen E. N. (1974). Yazın Terimleri Sözlüğü, Ankara: TDK Yayınları.

Greimas, A, J. (1972). Essais de Sémiotique Poétique, Paris:Larousse.

Kanık, O. V. (1963). Fransız Şïiri Antolojisi, İstanbul: Varlık Yayınları.

Karataş, T. (2001). Ansiklopedik Edebiyat Terimleri Sözlüğü, İstanbul: Perşembe Kitapları:5.

Necatigil, B. (2012). Şïrler, Bütün Yapıtları, İstanbul: Yapı Kredi Yayınları.

Le Nouveau Petit Robert (1993). Dictionnaire alphabétique et analogique de la langue française, Montréal, Canada.

Oktay, A. (1995). İnsan, Yazar, Kitap, Ankara:Ark Yayınevi.

Saraç, T. (1989). Fransızca-Türkçe Büyük Sözlük, İstanbul: Adam Yayınları.

Türk Dil Kurumu Sözlüğü (2007). Ankara: TDK Yayınları, A-K/ L-Z, 2 Cilt.

Vardar, B. (2002). Açılamah Dilbilim Terimleri Sözlüğü, İstanbul: Multilingual. 